\title{
"Land Was the Main Basis for Business": \\ Markets, Merchants, and Communities in Frontier Iowa
}

\author{
JEFF BREMER
}

AMERICANS and Europeans moved restlessly west across North America in the nineteenth century, searching for land and economic independence. People moved to new homes to "improve their material circumstances," argues historian David Danbom, and most of them accepted the developing market society that had emerged from the original 13 states in the late eighteenth century. ${ }^{1}$

Westward migration brought Euro-American families to Iowa for the first time in the 1830s and 1840s. They arrived with the intent of producing a market surplus to allow them to buy land and provide for themselves and their children. Such people needed goods that only others could provide-such as guns, cloth, nails, salt, and coffee-and they did not want to permanently leave behind the material comforts of their former homes. Merchants followed their customers into Iowa, providing goods

The author would like to thank Marvin Bergman, Pamela Riney-Kehrberg, Kevin Hill, and the anonymous reviewers for their assistance. A SHSI Research Grant aided in the research for this article.

1. Andrew R. L. Cayton and Susan E. Gray, "The Story of the Midwest: An Introduction," in The Identity of the American Midwest: Essays on Regional History, ed. Andrew R. L. Cayton and Susan E. Gray (Bloomington, IN, 2001), 15; David B. Danbom, Born in the Country: A History of Rural America (Baltimore, 1995), 79-80. 
for cash, barter, or credit. The first stores provided basic provisions, but by 1850 merchants in eastern Iowa were offering a wide variety of goods, from foodstuffs to spices, shoes, and paper.

Market participation did not harm the bonds between neighbors. Communities and neighbors assisted each other in many different ways, working together to complete a myriad of tasks that required mutual labor, including planting and harvesting crops, constructing buildings, traveling together to distant markets, and caring for sick neighbors. Iowa was, as farmer Thomas Warner wrote, "a good country for a poor hardworking man." 2

The American Revolution unleashed nascent commercial energies by weakening the hierarchal, paternalistic society inherited from the English and by breaking down barriers to the pursuit of individual economic gain. "Common, ordinary people with very vulgar and pecuniary interests" dominated American society in the early republic, argues historian Gordon Wood. Farmers were not isolated from markets and chose to participate in them. "Markets meant opportunity," Kim Gruenwald writes of the commercial society of the Ohio River valley. Emelia Hadley emphasized the American interest in market participation, writing in her diary in 1851, as her family crossed the continent from Illinois to Oregon, "Notwithstanding all the fine land I would not live here If you would give It to me[.] The great trouble would be [to be] so far from market." 3

Families in Iowa did not produce solely for local trade, and their economic actions were usually not limited by tradition or communal ideas. People came to Iowa to acquire land and improve their economic status. The ideal of the self-sufficient pioneer family was "inconsistent with the Iowa experience," argues historian Dorothy Schwieder. Most Iowa farmers wanted to produce a surplus and make a profit. Furthermore, their mentalite,

2. Thomas K. Warner to Hester Ann Warner, 10/5/1851, Thomas K. Walker Family Letters, State Historical Society of Iowa, Iowa City (SHSI-IC).

3. Gordon S. Wood, The Radicalism of the American Revolution (New York, 1993), 6-8, 308-12, 336, 369; idem, "The Significance of the Early Republic," Journal of the Early Republic 8 (1988), 18-20; James Henretta, "Families and Farms: Mentalité in Pre-Industrial America," in The Origins of American Capitalism: Collected Essays (Boston, 1991), 75, 81-87, 92-93, 97-98; Kim M. Gruenwald, River of Enterprise: The Commercial Origins of Regional Identity in the Ohio Valley, 1790-1850 (Bloomington, IN, 2002), 4; Mrs. E. A. Hadley Diary, 4/23/1851, SHSI-IC. 
or worldview, was not opposed to individual gain and market participation, as some historians have argued. ${ }^{4}$

IT TOOK SUBSTANTIAL RESOURCES to establish a farm, so many families did not own their own land. By the time Iowa opened to formal white settlement on June 1, 1833, an acre purchased from the federal government cost $\$ 1.25$. Settlers bought about one-third of Iowa's land directly from the federal government with cash; another 40 percent of the state's land was purchased using land warrants that veterans received for military service. (State land grants, including those to support railroad construction, and property given out through the Homestead Act, made up the rest of land sales in the state.) In addition to the cost of land, settlers needed capital to migrate west, as well as to purchase tools, seed, wagons, and livestock. Newcomers also had to feed themselves while awaiting their first crop. In the 1850 s it could cost $\$ 500-\$ 1,000$ to establish a 160 -acre farm; essential livestock, such as oxen, horses, cattle, and hogs, cost at least \$200. Expenses could run into the hundreds of dollars for the first year. Families might pay for property in Iowa by selling a farm in a state back east. But not all migrants were so fortunate. In 1860, 19 percent of farmers in Iowa were tenants who paid for rented property with a portion of their harvest. Families often labored for years to save money. Men worked as trappers or hired hands or practiced an artisan craft, such as tailoring, if they had such skills. Women might sell surplus eggs or butter. ${ }^{5}$

4. Dorothy Schwieder, Iowa: The Middle Land (Ames, 1996), 42-48; Glenda Riley, Frontierswomen: The Iowa Experience (Ames, 1994), 13.

5. Danbom, Born in the Country, 71; Jeremy Atack and Fred Bateman, To Their Own Soil: Agriculture in the Antebellum North (Ames, 1987), 111; Schwieder, Iowa: The Middle Land, 42-44; Clarence H. Danhof, Change in Agriculture: The Northern United States, 1820-1870 (Cambridge, MA, 1969), 103, 125; Robert E. Ankli, "Farm-Making Costs in the 1850s," Agricultural History 48 (1974), 51-52; Leland L. Sage, A History of Iowa (Ames, 1974), 52, 70; Bela Vassady, "New Buda: A Colony of Hungarian Forty-eighters in Iowa," Annals of Iowa 51 (1991), 40. The amount of land soldiers received varied greatly, as did requirements for their service. Veterans of the Mexican War, who had served at least one year, earned a warrant for 160 acres of land. See Roscoe L. Lokken, Iowa Public Land Disposal (Iowa City, 1942), 135-42. 
A. C. Sutliff is a good example of the American ambition to secure land and become involved in commerce. He moved with his family from Ohio in the late 1830s and settled in Johnson County in the early 1840s. Sutliff traveled several hundred miles searching for a good farm site. "I had not come as far as I had for chances as others. I was looking for the best and would go farther to get it." He found a "handsome situation for a farm," with fertile land, timber, and water near a navigable river. Sutliff and his family intended to live on the property as squatters, taking up residence before the federal government sold it. He wrote that he hoped "to make enough off the land before it is offered for sale to pay for it." Sutliff planned to produce butter and cheese, as the prairies provided great pasture for cattle. "The local advantages far exceed any other country I ever saw for doing business," he wrote to his brother. ${ }^{6}$

Kitturah P. Belknap also made this point in a reminiscence. Belknap and her husband had purchased 160 acres of land in Van Buren County that had not been sold by the federal government or even surveyed. They bought the land from squatters who did not legally own the land and who had left Iowa to return to Missouri. "We could settle on it and hold our claim and make improvements, but we must have cash to pay when it was surveyed and came into market." They saved every dollar they could to buy the property that they lived on. She sold butter and eggs and her husband made rails to earn money for groceries. They also sold pork and wheat they had ground, which they then hauled 60 miles to market. ${ }^{7}$

For many decades before Americans migrated to Iowa northern farmers had sold household surpluses to earn income. Farmers often sent extra farm produce to local towns to exchange for goods they needed or desired. Even in the mid-1700s, Massachusetts farmers traveled surprisingly long distances - an average of 26 miles, but as far as 175 miles - to market their farm produce. They sought items they did not produce, such as sugar,

6. A. C. Sutliff to Brother, 11/23/1838, A. C. Sutliff Letters, SHSI-IC. For information on Sutliff, see the entry for Charles McCune, Iowa Territorial and State Legislators Collection, State Historical Society of Iowa, Des Moines (SHSI-DM).

7. Kitturah P. Belknap, "History of the Life of my Grandmother," 3-6, SHSI-IC; Glenda Riley, Prairie Voices: Iowa's Pioneering Women (Ames, 1996), 12. 
tea, bricks, rum, salt, and flour. Travel increased in the following decades. ${ }^{8}$

New farming settlements on the frontier, as well as more established towns on the East Coast, found themselves tied into expanding market relationships in the late 1700s and early 1800s. "It took money as well as time to make a home in this new country," recalled Samuel Clough, who had lived in Iowa for nearly five decades by the time he decided to "sit down at the age of 74 to write a few past incidents and memoirs of my life, works, and travels." Clough wrote that he had needed money not only to buy land but also to purchase salt and oats as well as things like nails. Livestock was also an expensive investment. Most people wanted items that they found useful and that made their lives easier or more comfortable. Families also needed guns, powder, pots, sugar, and coffee. ${ }^{9}$

"From the very beginning, large numbers of settlers and farmers in this region had a strong commercial orientation," argues historian Allan Bogue. Families wanted land with easy access to markets. Sophia Standfield recalled that a group of men toured southeast Iowa Territory looking for a place to settle. One man, Henry Seaba, thought that some lands were too far from markets to be valuable and considered returning to Ohio. ${ }^{10}$

Farm households had to take part in commercial markets to earn money to buy and cultivate their lands. "The purpose of the farmer was to acquire land," wrote Iowa historian Irving B. Richman. A family made their living from the land, he argued,

8. Allan Kulikoff, From British Peasants to Colonial American Farmers (Chapel Hill, NC, 2000), 2-3; Paul A. Gilje, The Making of the American Republic, 17631815 (Upper Saddle River, NJ, 2006), 4, 241-44; Danbom, Born in the Country, 79; Winifred B. Rothenberg, "The Market and Massachusetts Farmers, 17501855," Journal of Economic History 41 (1981), 288-98; Robert A. Gross, "Culture and Cultivation: Agriculture and Society in Thoreau's Concord," Journal of American History 69 (1982), 45-46, 53.

9. Mrs. E. R. Troxel, "A Barefoot Soldier Becomes an Iowa Farmer: Samuel Clough, 1824-1900," Annals of Iowa 39 (1969), 615-17. Historian Allan G. Bogue traces the history of the market-oriented Savage family in Allan G. Bogue, "Twenty Years of an Iowa Farm Business, 1860-1880," Annals of Iowa 35 (1961), 561-77.

10. Allan G. Bogue, From Prairie to Cornbelt: Farming on the Illinois and Iowa Prairies in the Nineteenth Century, 93; Sophia Standfield, "History of Plank Township," 54, SHSI-IC. 
and their goal was to own and farm land for themselves and future generations. Shortly after the first Euro-Americans moved into Iowa, they searched for ways to make money. As early as 1835 in Scott County, bordering the Mississippi River, settlers sold coal they had dug out of the ground to steamboats. Residents of Bremer County, in northeast Iowa, sold muskrat pelts to earn an income to buy goods, such as bacon or coffee, at local stores. Some of the earliest white settlers of southeast Iowa Territory, near Burlington, sold surplus pork and lard to incoming families about 1840. Rachel Scott, who moved to Iowa with her husband, Allen, and their two children in the early 1840s, obtained sugar, tea, coffee, and "almost everything for her family" by exchanging butter, honey and whiskey at local stores. George Green, who settled near Cedar Rapids in eastern Iowa, wrote that the fertile land produced "bountiful crops." New families came to Iowa by the thousands every year before the Civil War. Newcomers consumed most of the surplus produced by those already living in the state. Green noted, "Land was the main basis for business." 11

FAMILY GOALS included providing land for children, which depended on favorable land values. John Garnavillo wrote to a friend, Louis Trombly, that if he came to Iowa he could "double your property in three years and live in one of the pleasantest countrys in the west." Garnavillo argued that good land with fine homes could be bought for less than a thousand dollars. He

11. Irving B. Richman, Ioway to Iowa: The Genesis of a Corn and Bible Commonwealth (Iowa City, 1931), 166; Willard Barrows, "History of Scott County, Iowa, Chapter II. First Settlement of Buffalo Township." Annals of Iowa, 1st ser., 1 (1863), 18; W. V. Lucas, Pioneer Days of Bremer County, Iowa: Compiled from Letters to the Waverly Democrat by Col. W. V. Lucas (Waverly, 1918), 62; Sage, A History of Iowa, 52-53; A. N. Kellogg, "An Interesting History of the County," published in Decatur Journal in 1930, 3-5, SHSI-IC; George Green, Green Family Papers, 43, Special Collections, University of Iowa Libraries, Iowa City. For information on Rachel Scott, see the 1850 Federal Census for Decatur County, Iowa. She is not identified in Kellogg's narrative. David Rich warned of the risks of buying expensive land. Settlers who had purchased land at \$3 per acre could make thousands of dollars when prices increased. But some land for sale cost \$18-\$20 per acre. "If we purchase at a high price there is but little chance for advance but great danger of a fall," Rich wrote. David Rich to brother, 7/27/ 1857, David Rich Letters, SHSI-IC. 


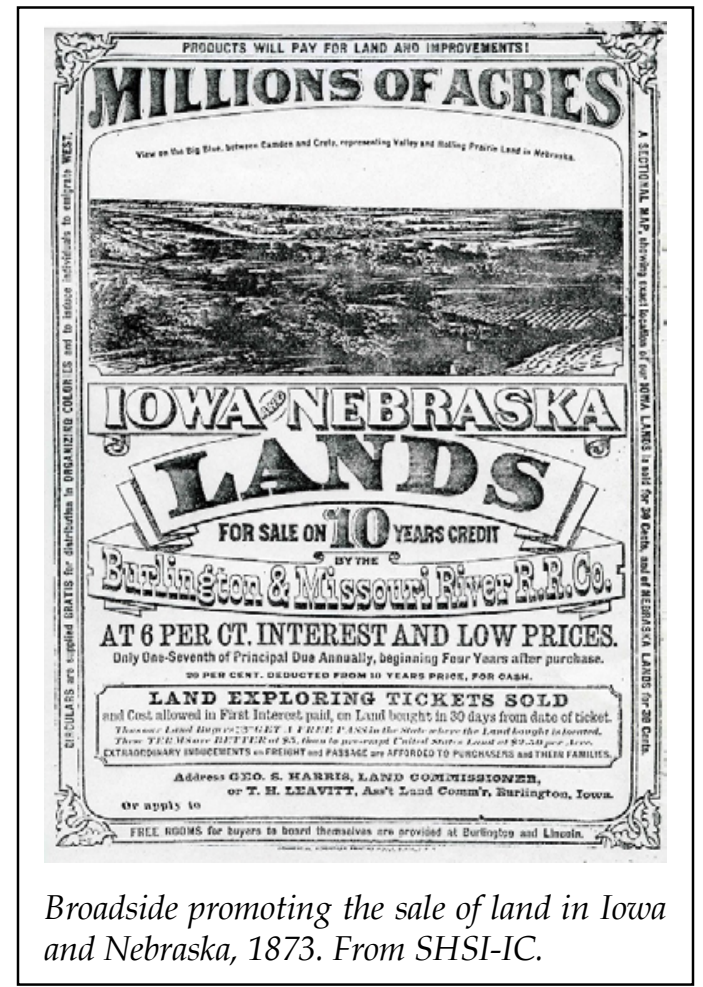

suggested that Trombly move to Iowa, where land values had doubled in value in one year. Prices increased quickly for land that was "near the market," which was accessed by a river. A friend who had visited him planned to buy a farm and leave behind rocky lands and an unhealthy country that had "nothing for their children." Iowa provided an opportunity to purchase fertile land in a healthy place that allowed families "to provide for their children," Garnavillo contended. ${ }^{12}$

In 1856 Reuben Ellmaker wrote to his brother in Oregon about the frantic land business around him in Jefferson County. Prices had steadily increased, leading some families to sell their property and move farther west in the state. Ellmaker told of a neighbor who had sold his property to go "a little further west

12. John Scott Garnavillo to Louis M. Trombly, 12/19/1849, Merle Davis Collection, SHSI-IC. 
and enter or buy lots of land for his children." Another neighbor sold out for \$50 per acre and left the state. Land prices had skyrocketed as an incoming railroad line provided access "within 4 or 5 days of any of the Eastern cities. Therefore there is a prospect for a Market for all time to come." 13

Bad harvests or bad luck could, however, undermine a family's goal of buying their own land. Robert Christie, who had lived near Pleasant Valley in Iowa Territory wrote, "My last years farming proved a complete failure. I rented five acres of ground at six dollars an acre and did not realize ten dollars for the whole crop." Worse yet, he had discovered that his lands were to be sold by the federal government the next year. "This is a heavy blow for those that are not prepared to pay and unexpected to all." He wrote to family members and asked for money. Christie worried that he might have to borrow it at high interest rates. "I suppose there will be a money lender at the sale." Such individuals loaned settlers money at 20 to 33 percent interest for five years, he complained. Christie called such loans "the hardest kind of usury." Fortunately, his brother Lyman sent his family $\$ 400$ to secure their property. ${ }^{14}$

Ephraim Gard Fairchild did not fare as well as Christie. He suffered badly in the late 1850s, after the Panic of 1857 brought the economic boom of the 1840s and 1850s to a halt. His family lived near Wyoming, Iowa, paying half of the corn crop to rent the land. He wrote that he thought he might make a better living in Iowa than New Jersey. "I don't have to work as hard here as I did in Jersey," he wrote to his parents in the spring of 1857, after moving to the state. Squirrels and gophers plagued his fields, but his harvest was good. However, prices for farm goods collapsed in the wake of the banking panic that brought an economic recession to the United States in the late 1850s. "All kinds of produce is down very low and money is very scarce," he wrote. "It has been hard times out here," he noted in 1858. That summer, there was "nothing the farmers have that will

13. Reuben Ellmaker to brother, 4/17/1856, Enos Ellmaker Letters, SHSI-IC; Portrait and Biographical Album of Jefferson and Van Buren Counties, Iowa (Chicago, 1890), 547.

14. Robert Christie to Brother Lyman, 1/31/1840 and 5/8/1840, Robert Christie and Mary Christie Letters, SHSI-IC. 


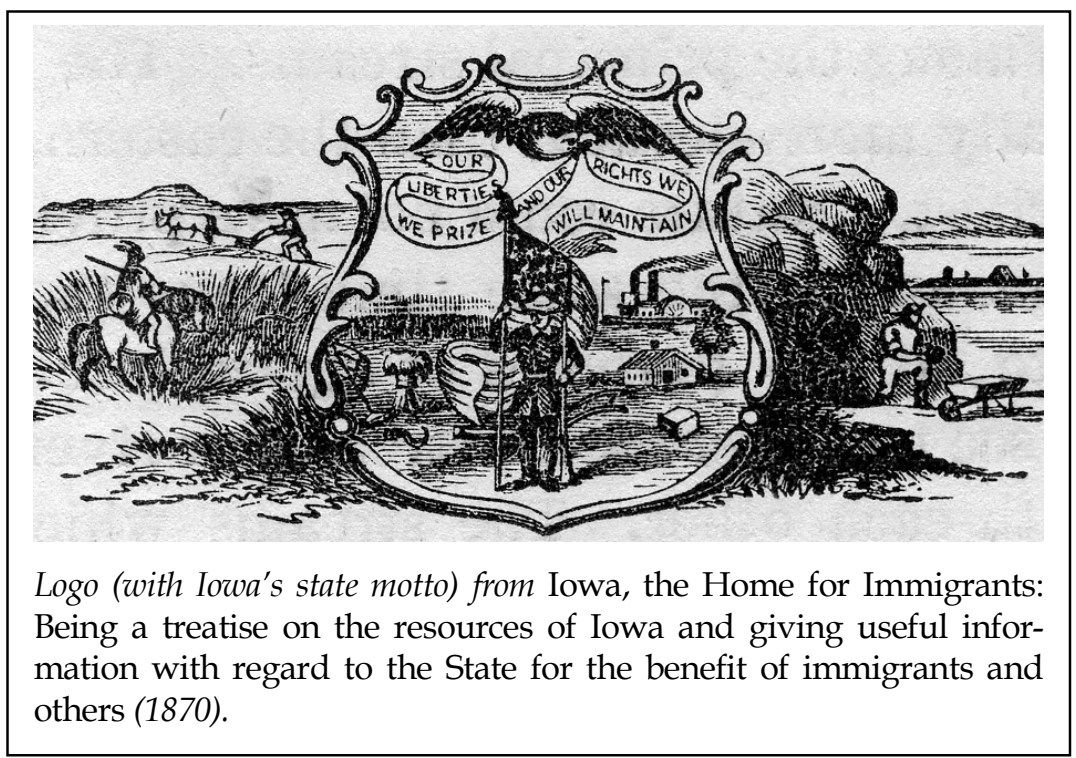

fetch money." His wheat and oat crops failed, and hail damaged his corn. In one of his last surviving letters, he asked for $\$ 100$ from his parents to return home to live with them. ${ }^{15}$

FARM FAMILIES who survived in Iowa for a year or more often found that incoming settlers gave them a market for their surplus. Dutch farmers in central Iowa found "ready consumers in the increasing population of the neighborhood." Sjoerd Aukes Sipma, who immigrated from Holland to Iowa, wrote in a letter in 1848 that the farmers living near him "made a good living" because of the continual demand for food from new families. He also noted that buying land near the Mississippi River provided farmers with better transportation and access to markets; however, such property was much more expensive. Mary Parsons Christie noted that the demand for farm produce by immigrants often drove prices up. She wrote to a friend that a lack

15. Ephraim Gard Fairchild to Father and Mother, 4/9/1857, 6/14/1857, 7/25/ 1857, 12/6/1857, 2/21/1858, 6/6/1858, 10/2/1858, E. G. Fairchild Letters, SHSI-IC; Earle D. Ross, Iowa Agriculture: An Historical Survey (Iowa City, 1951), 50 . 
of supply and a "flood of immigrants who must have something to eat" led to a good price for farmers. "The market is so excellent," she boasted. Similarly, Gro Svendsen sold melons to "wayfarers passing by" her home in Estherville. ${ }^{16}$

During the California Gold Rush, Iowa farm families sold surplus hay and corn to emigrants heading west in the spring before grass had grown for their livestock to consume. Thousands of travelers provided a "good home market" for Iowans in eastern Iowa, wrote Benjamin F. Gue. James Peery Schell wrote of how the gold rush provided an opportunity for his family and their neighbors to sell their farm goods to passing migrants. He recalled that the road that passed his family's farm near West Branch was "transformed into a living stream of eager westbound emigrants." Travelers often stopped at farmhouses. "Markets many miles distant were now brought to their very doors, and easily ranked among the best in the world." 17

The increased demand for agricultural production led to steep increases in prices that farmers received for their goods. The price for a dozen eggs or a pound of butter went from five cents up to 25 to 30 cents. "Beef, poultry, milk, vegetable, flour and feed were all in active and daily demand." The price of corn went up by ten times. Schell wrote that this was a "wonderful opportunity" for farmers struggling to pay off debts and save up money. Robert Pitzer, who lived near Winterset, recalled long lines of California-bound wagons near his home. "Now we were in luck," he wrote. The price of corn eventually reached one dollar a bushel and "money rolled in," as his family sold everything they could to migrants at high prices. ${ }^{18}$

16. Jacob Van Der Zee, The Hollanders of Iowa (Iowa City, 1912), 86-87; Mary Parsons Christie to Beloved Friend, January 1839 (no exact date), Mary Parsons Christie and Robert Christie Letters, SHSI-IC; "Recollections of E. T. Rice," SHSI-DM; Sjoerd Aukes Sipma, 9/26/1848 letter, SHSI-IC; Pauline Forseth and Theodore C. Blegen, Frontier Mother: The Letters of Gro Svendsen (Northfield, $\mathrm{MN}, 1950), 71$.

17. Benjamin F. Gue, History of Iowa from Earliest Times to the Beginning of the Twentieth Century, vol. 1, The Pioneer Period (New York, 1903), 261; James Peery Schell, "Seventy Years Beyond the Mississippi, 1845-1873," James Peery Schell Papers, Special Collections, University of Iowa Libraries, Iowa City.

18. Ibid.; Robert Claiborne Pitzer, Three Frontiers, Memories, and a Portrait of Henry Littleton as Recorded by His Son (Muscatine, 1938), 57. 


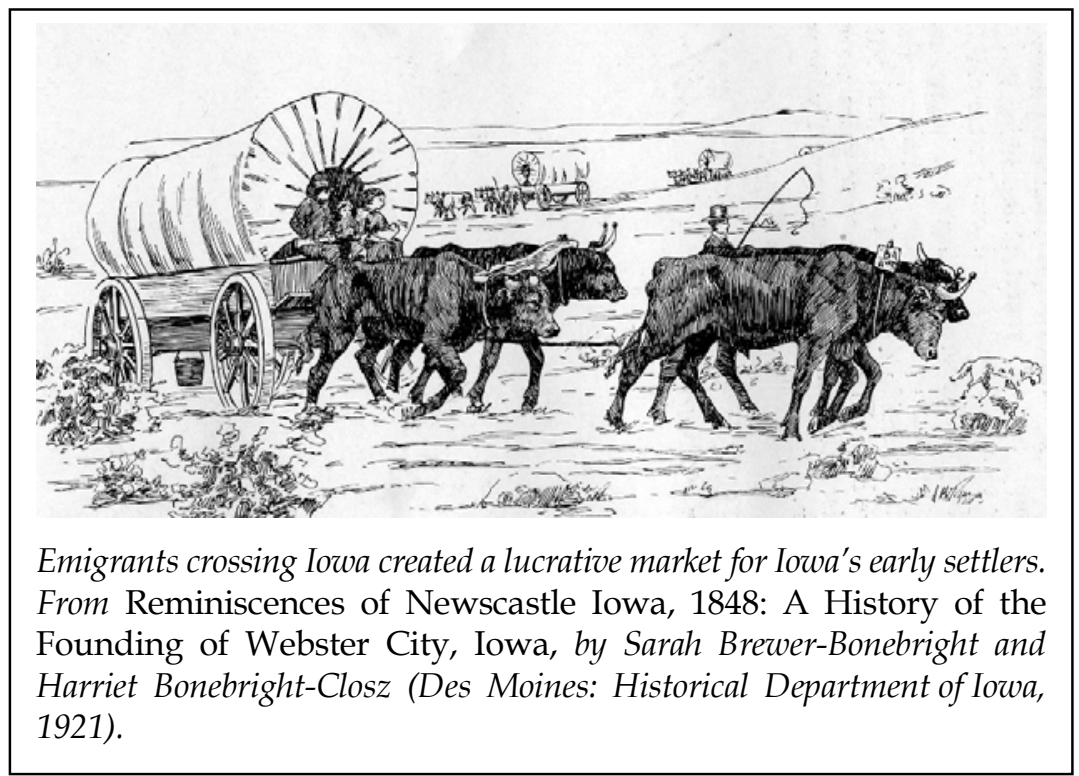

As settlement moved west across Iowa, the process of market seeking migrated west as well. In western Iowa, farmers butchered hogs in the winter and made long trips to Council Bluffs in one day. Decades after farmers in eastern Iowa took surplus farm produce to Mississippi River towns, families on the other side of the state moved their material to Missouri River towns. There, farmers found themselves suffering from the same isolation from markets that those a generation before had endured farther east. They sold their pork to buyers who resold it to wagon trains heading across the plains to Denver and mining camps. ${ }^{19}$

The laborious process of farm building could reduce commercial interaction for several years, but the desire to produce a surplus and earn some income was rarely ignored. In Iowa, farmers found people to buy their grain, as western migrants, gold seekers, and Mormons moved across the state. One farmer sold the hay that had been the roof of his stable to an emigrant party in 1850. Another man employed his livestock to haul logs, which he sold for 25 cents each, allowing him to buy food for his

19. Herbert Quick, One Man's Life: An Autobiography (Indianapolis, 1925), 207; Van Der Zee, The Hollanders of Iowa, 86-88; "Recollections of E. T. Rice." 
family. Those who lived in the western parts of the state took corn and wheat to Council Bluffs, where they sold their surplus to merchants supplying emigrants or miners heading across the plains. Sam Young wrote to a friend in 1853 that migration into and through Iowa had driven up prices for farm goods. The market for corn, pork, and wheat was good, and the prices for cattle and horses were "very high." Young bragged, "I say give me Iowa and you may have all the balance of the states." 20

THOSE WHO COULD STAY in Iowa needed money to pay taxes and buy items at local stores, because most people did not want to live primitive subsistence lives. The production of foodstuffs for household consumption continued, even as commercial production increased. Sheep provided wool that could be used for family clothing or sold in nearby towns. People consumed chickens if the retail price was too low. Apples could also be sold or kept for family use. While farms provided sustenance, markets could provide profit and comfort. Thus the success of the farm household required a mix of strategies, which historian Richard Bushman has called "composite farming." Market participation helped families meet their needs but did not displace traditional farm production for family consumption. Iowa reflected the "dual nature" of this economic system. Farms existed in an increasingly commercial world, and midwestern families, including those in Iowa, produced a larger surplus per person than farms in the Northeast. ${ }^{21}$

20. Bogue, From Prairie to Cornbelt, 123, 143; Sidney Halma, "Railroad Promotion and Economic Expansion at Council Bluffs, Iowa, 1857-1869," Annals of Iowa 42 (1974), 372-75; Samuel K. Young to T. K. Warner, 2/6/1853, Thomas K. Warner Collection, SHSI-IC; “Early Pioneer Days, As Remembered by John Hall," SHSI-IC.

21. Richard Lyman Bushman, "Markets and Composite Farms in Early America," William and Mary Quarterly, 3rd ser., 55 (1998), 364-66; Atack and Bateman, To Their Own Soil, 11, 13, 226; Richard F. Nation, At Home in the Hoosier Hills: Agriculture, Politics and Religion in Southern Indiana, 1810-1870 (Bloomington, IN, 2005), 87-89, 122-27; N. Tjernagel, "Pioneer Animal Lore," Annals of Iowa 31 (1953), 606; Margaret E. Archer Murray, "Memoir of the William Archer Family," Annals of Iowa 39 (1968), 362; Howard Raid, "Migration From Germany to Iowa by Mennonite Settlers," 4, SHSI-IC. 
Farming in Iowa reflected this form of composite agriculture. The family of Mary Ann Swaney migrated to Iowa Territory in the spring of 1839 with a group of people who had left Ann Arbor, Michigan. After settling in Jackson County in eastern Iowa, about a dozen miles west of the Mississippi River, they suffered "hard times" in the late 1830s and early 1840s, after the Panic of 1837 brought a harsh recession to the nation. Swaney wrote, "Our money all gone, no credit," noting that necessity brought "greater economy" to the family. They survived by feeding themselves until they "raised a surplus and were in a measure independent." George C. Duffield wrote that his father sought to acquire 160 acres of land to grow corn and other crops to feed his family. The family also used the open prairie lands to pasture livestock. "Especial effort was made to acquire hogs and cattle." Livestock would be collected in the fall and prepared for market sale in winter. 22

Two additional families provide examples of this mix of subsistence and market farming. The family of Margaret Archer Murray migrated to Iowa in 1846 and established a farm in Jones County, in eastern Iowa. They produced much of their own food, but her mother also sent chicks and butter to market for sale. Her father took pork to Davenport to sell, then purchased supplies for the family. They also sold apples from their orchard to men who picked and packed the fruit in barrels. The Murray family sold dried peaches, too. Mary Lacey Crowders's mother invested in milk cows and made butter for market. It was packed in 100-pound crocks and tubs and stored in their cellar until taken to Algona, 30 miles away, for sale. They used money earned from such sales for winter clothing and supplies, such as groceries. The Crowders women and children helped support their family by growing fruits and vegetables, raising chickens for food and eggs, and producing butter for exchange. ${ }^{23}$

Iowans pursued opportunities to produce, harvest, or hunt items for sale or exchange. They hunted birds, with one town's residents exporting 760 dozen quail and several tons of prairie

22. Mary Ann Swaney, "When Jackson County Was 'Far West,'" a letter to Mrs. Van Der Walker, 1884, SHSI-IC; "Memories of Frontier Iowa Related by George C. Duffield for the Annals of Iowa," 11-14, 37, SHSI-IC.

23. Riley, Prairie Voices, 130-31, 184-86. 
chickens via railroad. Families also sold salted meat or smoked hams to railroads for sale in eastern cities. Income from the sale of wild game brought "a large sum of money" and helped families pay their taxes, noted Clarence Ray Aurner, who collected pioneer lore in a series of short books. Families butchered hogs and took them to Davenport to sell. They bought milk cows and raised poultry so they could sell butter, eggs, and beeswax that they collected or "anything we could spare off the farm," recalled Margaret E. Archer Murray, who lived near Anamosa. Children gathered blackberries or wild grapes to exchange for groceries. Families then bought items they needed from local stores. ${ }^{24}$

FAMILIES ARRIVED in Iowa intending to produce a market surplus to allow them to buy land or pay debts, but distance often interfered with the market motivations of Iowa's farm families. W. V. Lucas recalled, "A market for their products was the problem that worried the farmers as much as did the producing." 25

Before railroads remade the transport map of Iowa, surplus farm goods had to be moved to towns for sale. Families hauled their surplus grain, wheat, oats, and animal skins, sometimes halfway across the state, to sell or exchange so they could make their spartan homes more comfortable. Irving B. Richman described how the "roads were alive" with hogs on the way to market. A hog, he noted, was but 15 to 20 bushels of corn on four legs. "Wagons would be loaded both ways, bringing back supplies for their owners and neighbors or for the country store," wrote historian George F. Parker. Sarah Brewer-Bonebright recalled that settlers near Webster City made long trips to Des Moines or Dubuque to exchange furs and hides for store goods in the 1850s. Such journeys, which often took four weeks, linked remote areas in the center of the state to Mississippi river towns tied to the national market by steamboats. Robert Ray Latta re-

24. Clarence Ray Aurner, Iowa Stories, Book One (Iowa City, 1918), 103-4; Clarence Ray Aurner, Iowa Stories, Book Two (Iowa City, 1918), 108; Murray, "Memoir of the William Archer Family," 359, 362; Don Buchan, "Pioneer Tales," Annals of Iowa 38 (1966), 477-78.

25. Lucas, Pioneer Days of Bremer County, 58. 


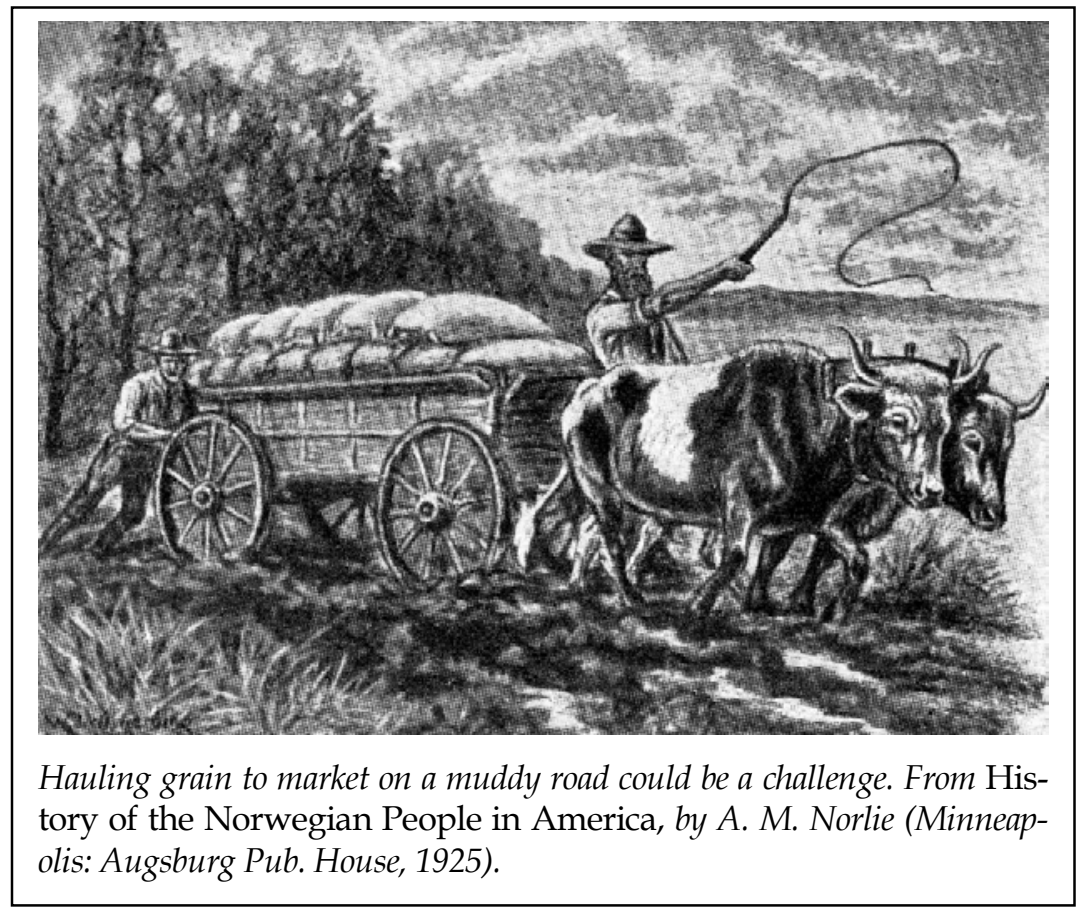

called that he had traveled with his father 150 miles to reach Burlington about $1850 .{ }^{26}$

Waterways served as useful transport for Iowans. Since markets were hard to reach and money was scarce, local residents built flatboats and other craft to send surplus goods to markets before railroads arrived. Those who lived near rivers floated surplus goods down the Cedar or Des Moines rivers and then down the Mississippi to St. Louis when they could. James Marsh wrote that the first settlers north of Des Moines built a flatboat, which they loaded with their surplus cheese, butter, wheat, and maple sugar. They then floated down the river, selling and trading their goods for provisions, which they loaded onto the boat. The group then poled their craft back up the river

26. Richman, Ioway to Iowa, 252, 270-75; George F. Parker, Iowa Pioneer Foundations, 2 vols. (Iowa City, 1940), 1:220, 329-31; Sarah Brewer-Bonebright, Reminiscences of Newcastle, Iowa, 1848: A History of the Founding of Webster City, Iowa (Des Moines, 1921), 26, 43, 83-84; Robert R. Latta, Reminiscences of Pioneer Life (Kansas City, MO, 1912), 19. 
to their homes. Farm families in southeast Iowa also built large flatboats to carry their surplus to St. Louis or as far south as New Orleans. Cargoes were sold for cash, and primitive flatboats were broken up and sold for lumber. Crew members returned upriver by steamboat. H. H. Green wrote that boys built small rafts from logs uprooted by spring floods on the Mississippi River. They then spent days hunting and fishing on the river, filling barrels with fish they caught and salted for market. "Ready sale was always found for both fish and game." 27

People took advantage of commercial opportunities when they were available, even if access was difficult. In central Iowa, the Des Moines River provided a route for small steamboats when the river was not too low. In 1859 the Charles Rogers made its way upriver to Fort Dodge full of sugar, coffee, tobacco, flour, and other goods. Near Boone, the boat sold $\$ 110$ of its stock to a farmer who was "very anxious for supplies." In Fort Dodge the boat sold all of its remaining goods by noon the day after it arrived. Fort Dodge served as a good market for nearby farmers but often lacked much in the way of store inventory, so area farmers often took surplus grain and livestock, as well as fur and pelts, to Des Moines to exchange at stores in the city. After the Panic of 1857 "commercial stagnation" hit northwest Iowa and there was little demand for surplus farm goods. Fort Dodge residents floated logs downriver to Des Moines, which suffered from a shortage of lumber as the new capital was undergoing a building boom. ${ }^{28}$

Even if they had access to markets and stores, not everyone could afford to take advantage of what they had to offer. Mary Jane Parsons, who lived near Jefferson, noted that her family could not afford to buy coffee "all the time" and were also too poor to buy shoes. They were often short on flour their first win-

27. James Marsh, "First Iowans Settled by Streams," Annals of Iowa 31 (1952), 229; H. H. Green, The Simple Life of a Commoner: An Autobiography (Decorah, 1911), 32; Charles A. White, "Early Homes and Home-Makers of Iowa," Annals of Iowa 4 (1899), 193.

28. Caleb Forbes Davis and James Cox Davis, "The Autobiographies of an Iowa Father and Son," Annals of Iowa 19 (1935), 492-94; A History of Boone County, Iowa: Containing A History of the County, its Cities, Towns Ec: Biographical Sketches of its Citizens, ... E Ec, Ec. (Des Moines, 1880), 335, 477. 
ter in Iowa. They built their first fences without nails because "we did not have money to buy everything and nails were expensive in a new wild country where everything had to be freighted in by oxen or horses." Sarah Morse wrote to her aunt in 1858 from Genoa Bluffs in Iowa County, complaining of the lack of a store in their neighborhood and of the resulting high prices of sugar and butter, as well as the limited availability of goods. "No store here at present, both stores closed the next week after we came." She continued, "I try not to think of the luxuries I am deprived of any more than I can help." 29

When railroads linked western Iowa to the eastern portion of the state-and to the rest of the United States - families took advantage of opportunities to buy and sell goods on a more regular basis. "It was the railroad that made the country," wrote Albert Butts. Before railroads, "every single item of building material for houses and barns, posts and fences, and fuel for heating and cooking had to be hauled in by team and wagon" a long way at considerable cost of time and labor. Benjamin Gavitt recalled that his mother in Harrison County had sold hogs to towns established along railways for shipment to Chicago. She also sold her butter and eggs to those places to earn money for groceries. W. E. Sanders, who lived about 15 miles south of Pella, remembered when the first railroad came through south central Iowa in 1876. He wrote that the abundance of lumber from sawmills on the Mississippi River allowed farmland to be fenced in and that frame buildings replaced log cabins. ${ }^{30}$

Reuben Ellmaker wrote to his brother of the changes that a new railroad line brought to Jefferson County when it passed within a mile-and-a-half of where he lived. He noted that heavy items such as iron or salt were much cheaper than before the

29. Mary Jane Parsons, "Memoirs of the Pioneer Life of Mary Jane Parsons," 79, 82, 85, Iowa Women's Archives, University of Iowa Libraries, Iowa City; Sarah Morse to Aunt Eliza, 9/6/1858, Morse Letters, SHSI-IC; Glenda Riley, ed., "The Morse Family Letters: A New Home in Iowa, 1856-1862," Annals of Iowa 45 (1980), 212-13, 218.

30. A. T. DeGroot, ed., Eighty Years in Iowa, written by Benjamin H. Gavitt, in His 81st year, at Des Moines (Los Angeles, 1948), 62; Albert Butts, "A Calhoun County Pioneer," SHSI-IC; W. E. Sanders, "Cedar Brakes and Hamilton Prairies: A Century of Change in Iowa Pioneer Life," Annals of Iowa 34 (1958), 437, 453. Gavitt's book is a typed and bound reminiscence. 


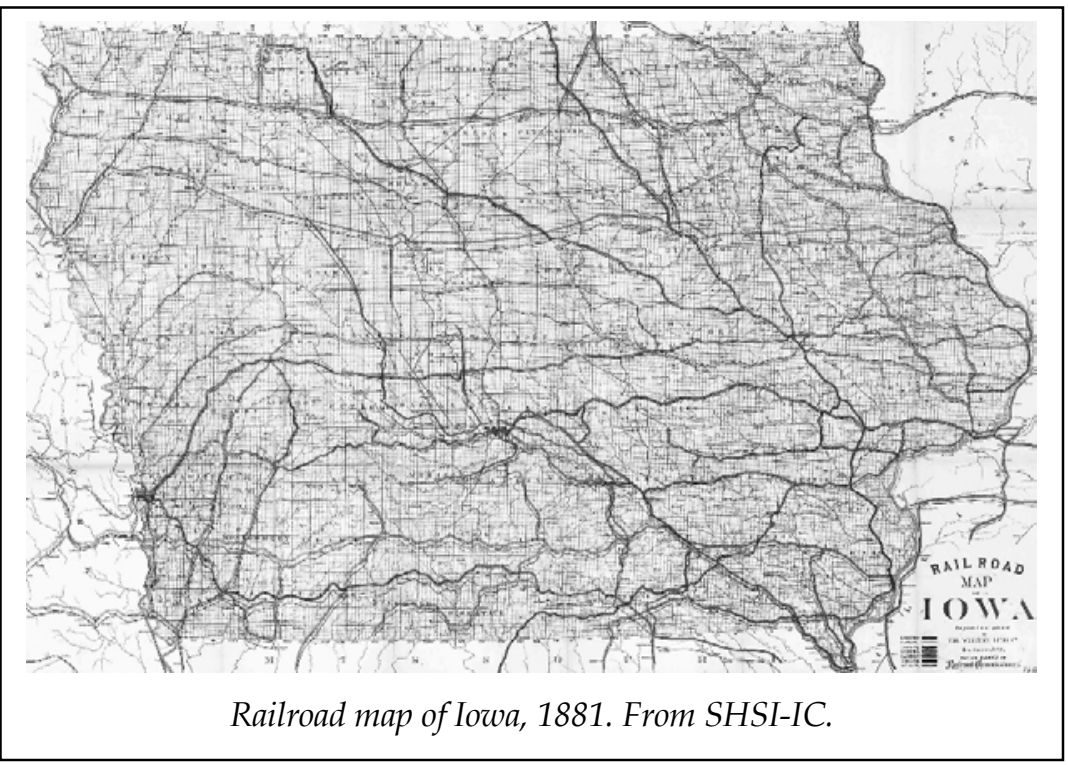

railroad arrived. Most prices fell. "In fact, our groceries and everything we have to buy is Cheaper, generally speaking." Improved transportation also made it easier to reach markets outside Iowa. "If we have anything to sell it brings the cash right at home." Ellmaker observed that large amounts of lumber were brought into Iowa by the railroad line. ${ }^{31}$

The impact of railroads was not entirely positive, though. Historian David B. Danbom notes that railroads "were absolutely necessary, but their practices were detestable." Those who were initially happy to have a railroad line nearby often became quickly discouraged. High freight rates, political corruption, and the exploitation of farmers enraged customers. Later in the nineteenth century many farmers in Iowa joined the Grange, an agricultural mutual aid society that flourished in the 1870s. It fought high transportation costs and attempted to improve the economic situation of farm families through cooperative buying that reduced costs for wagons, tools, and other machinery. ${ }^{32}$

31. Reuben Ellmaker to brother, 2/18/1859, Enos Ellmaker Papers, SHSI-IC.

32. David B. Danbom, Sodbusters: How Families Made Farms on the 19th-Century Plains (Baltimore, 2014), 86; Myrtle Beinhauer, "Development of the Grange in Iowa, 1868-1930," Annals of Iowa 34 (1959), 597-604, 609-12. 
MERCHANTS followed their customers into the newly settled areas of Iowa, providing the "necessities of life" on credit and meeting the material demands of farm families. Initially, they sold staple items from tools to foodstuffs from towns in eastern Iowa, but their ability to access customers was limited by inadequate transportation links to central and western sections of the state. In the 1830s and 1840s, "there was little inducement for the merchant to exchange goods for farm produce, as the expense of getting it to market left no profit." 33

In 1840 a merchant named Addison Daniels moved to Marion, a town near Cedar Rapids. He built a log cabin that he intended to use as a store. It was only about 400 square feet and stocked a "somewhat coarser and cheaper grade" of items than would be found in such a store 50 years later, when George Carroll wrote of the place. Despite its basic set of goods and small size the store became the "great commercial center of the county and the settlers came in for miles around" to get the merchandise they desired. ${ }^{34}$

One of the first merchants in Fort Madison, Charles Brewster, arrived in 1844 and opened up a dry goods store in the town. His variety of goods expanded over time, especially after the Civil War, when railroads and increased industrialization improved the availability of items. Brewster took pork, corn, wheat, butter, and beeswax in exchange for coffee, spices, medicine, soap, and shoes. In the 1850s he shipped butter, eggs, and oats to a lumber company in Minnesota Territory; he also sold lard and pork to firms in St. Louis and New Orleans. In doing so, he helped develop markets for agricultural goods in southeastern Iowa. Barter dominated early transactions, with some merchants in smaller towns buying hogs or other livestock that could be driven to towns such as Keokuk. ${ }^{35}$

Towns and cities, from Dubuque to Des Moines, served as centers for trade and stores. In Dubuque, farmers found a wide

33. L. F. Andrews, Pioneers of Polk County, Iowa, and Reminiscence of Early Days, 2 vols. (Des Moines, 1908), 1:56.

34. George R. Carroll, Pioneer Life in and around Cedar Rapids from 1839 to 1849 (Cedar Rapids, 1895), 118.

35. John E. Pilcher, "Charles Brewster of Fort Madison: A Profile in Enterprise, 1845-1875," Annals of Iowa 44 (1979), 603-6, 610-13. 


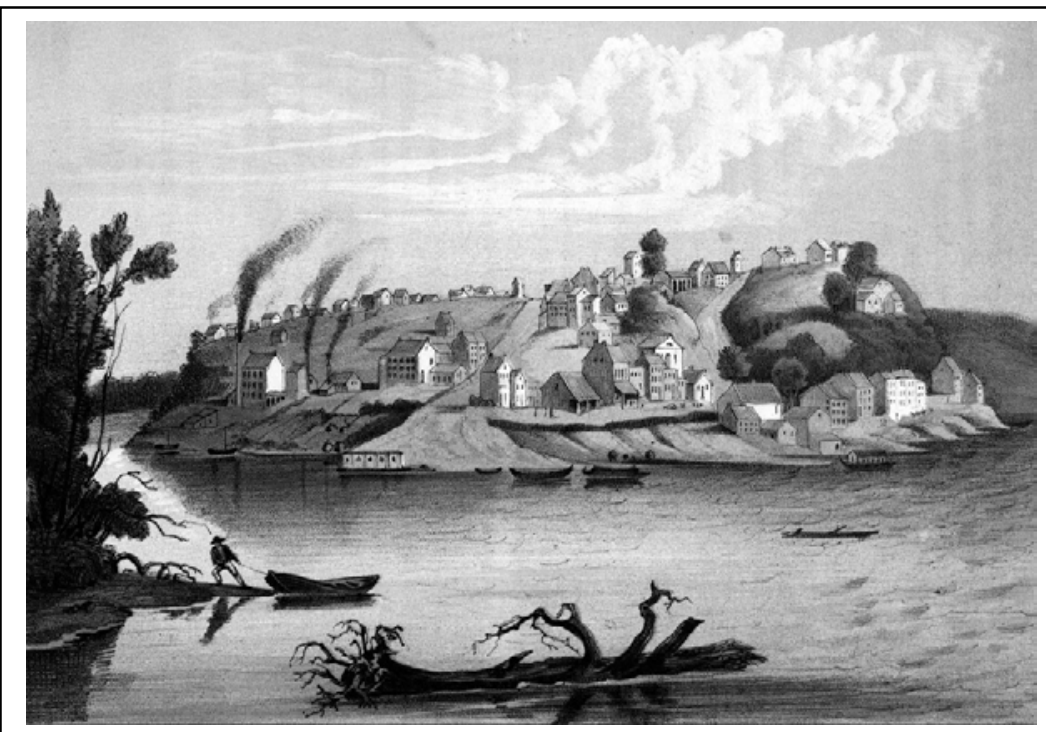

Sketch of Keokuk, ca. 1846. From Das illustrirte Mississippithal, by Henry Lewis (1854).

variety of goods brought to eastern Iowa from across the state. Even in 1840, consumers could purchase coats, caps, tea, and coffee pots, as well as spades, shovels, knives, and matches for sale in the town's stores. In Keokuk wagons unloaded pork and produce and loaded items such as salt, iron, and groceries that were to be transported to merchants across southern and central Iowa. Farmers in Jackson County, adjacent to the Mississippi River, transported barrels they had made to Galena, Illinois. A local history reported that "a chief industry of the county was coopering" and that most settlers engaged in building flour, pork, and whiskey barrels. Some men made shingles for sale, as well. In the 1850s Des Moines became a market center, and families came to the city to sell surplus produce and purchase goods. One storekeeper traded two pounds of salt for a bushel of wheat. In Boone, 40 miles northwest of Des Moines, merchants took furs, pelts, and all kinds of farm products in exchange for goods at their stores. ${ }^{36}$

36. Annals of Jackson County, Iowa, Issues 1-7 (Maquoketa, 1905), 60, 66, 71; Andrews, Pioneers of Polk County, 1:97, 149, 208; History of Boone County, Iowa, 335. 
Early stores stocked only the most basic goods and "not very much of that," recalled an old pioneer in 1887. In March 1839, before the Mississippi River opened to river traffic and the ice melted, there was not a yard of muslin of calico or even a pound of salt in eastern Iowa, one writer claimed. The arrival of a steamboat was "an event of great interest," and a town's population turned out. As goods were unloaded, customers eagerly awaited the opportunity to purchase coffee, flour, or bacon. There was little money in the territory at the time; most items were bought via barter or store credit. In Brighton, Iowa, south of Iowa City, merchant I. H. Friend sold goods to local families "for many miles around," recalled C. C. Heacock. Most business was accomplished via barter, with Friend exchanging his store goods for local products, such as pork. The merchant then arranged for his surplus to be hauled to Burlington. He sold salted pork to firms in Philadelphia. In one year in the 1840s he reportedly made over $\$ 6,000$ from shipping hams (roughly equivalent to $\$ 150,000$ in 2016 dollars). ${ }^{37}$

A sample of extant and legible store ledgers and account books shows increasing commercial participation by store customers in eastern Iowa from the late 1830s to the early 1850s. A fragmentary account book from an unknown store in Dubuque details a variety of transactions from 1838 to 1841 . Items most often purchased at the store included alcohol, tobacco, coffee, shoes, flour, shirts, and socks. Some weeks the only thing that sold was whiskey. Items like cloth or spices, such as pepper, were purchased only rarely. Business was carried out by credit, with payment often made with corn, bacon, or lead. Several accounts, including that of "Mack Donald," were paid through work. This system of barter and exchange is a good representa-

Rev. Charles E. Brown, who lived in Maquoketa in 1850, recalled that the demand for mercantile goods was so strong that he once returned from pastoral business at Rock Island with "a heavy load of goods for one of our merchants." Charles E. Brown and Phillip Perry Brown, Personal Recollections, 1813-1893, of Rev. Charles E. Brown, with Sketches of His Wife and Children and Extracts from an Autobiography of Rev. Phillip Brown, 1790-1862, with Sketches of his Children and the Family Record, 1767-1907 (Ottumwa, 1907), 54.

37. Old Settler's Reunion, August 31, 1887, 3-4, SHSI-IC; C. C. Heacock, Local Reminiscence of the Early History of Brighton, Iowa (Brighton, 1900), 17-20. 
tion of how a store would have operated in a frontier community populated by miners with basic needs. 38

Three store account books from the 1840s, and continuing into 1850, from Iowa City and Fort Madison, show an evolution of consumer behavior as eastern Iowa was rapidly transformed by the migration and settlement of tens of thousands of people. Iowa had opened to settlement in 1835, and there were fewer than 23,000 white residents in the territory in 1840. In the 1840s, more than 150,000 people moved into Iowa, and the territory became a state in 1846. The flood of people led to settlement across the eastern third of the state by 1850 and an increased demand for store goods. ${ }^{39}$

The first of these records is from the store of Gower and Holt, located in Iowa City. A section of its account book from late 1846 survives. The Gower and Holt store sold a much more diverse variety of goods than the store in Dubuque. While the Dubuque store sold alcohol, tobacco, and coffee, those products made up less than 10 percent of the sales at the Iowa City store. The customers of Gower and Holt bought butter, candles, potatoes, shoes, cloth, nails, flour, and eggs. On October 6, 1846, for example, the business sold candles, tobacco, flour, cinnamon, and molasses. A week later, on October 13, customers purchased shot, candles, lard, onions, lead, apples, eggs, and paper. ${ }^{40}$

A ledger from an early Fort Madison store also survives. The G. R. Espy account book has entries from 1848 and 1849. The Espy store and mill regularly sold an assortment of nonalcoholic goods, including sugar, coffee, spices, and a variety of cloth, such as calico and muslin, as well as buttons, thread, lace, and other material related to making or repairing clothing. Some candy, tea, molasses, and tobacco were also sold. Items that were sold only rarely included brooms, pitchers, knives, or

38. Entries for June 1838-January 1839, May 15, 1839-December 15, 1839, and July 1841, Account Book, Dubuque Iowa Store, 1837-1841, SHSI-IC.

39. Cardinal Goodwin, "The American Occupation of Iowa, 1833 to 1860," Iowa Journal of History and Politics 17 (1919), 88-89, 96-97.

40. Entries for September 28-October 17, 1846, Gower and Holt Iowa City Store Account Book, SHSI-IC. This is a photocopy of a fragmentary record, and some dates and entries are missing. It provides useful information to compare with other sources, however. 
a bottle of ink. A typical entry, on April 29, 1848, recorded the sale of five pounds of coffee, three pounds of sugar, and a gallon of molasses to D. Richardson. ${ }^{41}$

A final store, William Wright's in Iowa City, shows the greater diversity and larger number of goods sold in the late 1840s. Wright's store, like the previous examples from Iowa City and Fort Madison, stocked a diversity of foods, drinks, personal goods, and clothing-related items. As with the other stores, coffee, tobacco, cloth, sugar, molasses, and shoes sold often. Some of those items sold on most days, with tobacco and coffee being the items that sold most often. Hats, shoes, and nails were also bought regularly, but customers bought other items, such as peppermint, combs, paper, or butter, only rarely. ${ }^{42}$

FARM FAMILIES sought opportunities to sell their surplus farm goods, just as towns pursued their business. Davenport became the dominant trading center for Iowans on the western bank of the Mississippi River before the Civil War, while places such as Council Bluffs and Sioux City functioned as economic outposts for western Iowa in the 1840s and afterwards. Rivers served as highways for the movement of people and goods, with steamboats providing cheap and regular transport until railroads began to replace them in the Midwest in the 1850s. Merchants and peddlers in Davenport sold fruits and vegetables in the 1830s, later selling dry goods and extending credit to local farmers. They eventually purchased surplus grain from farms in nearby counties. The town quickly became a central location for trade, tying agricultural producers in eastern Iowa to urban areas such as St. Louis. Beginning in the late 1850s, railroads replaced rivers as transportation for Iowa, as they provided stable costs and access to Chicago. Railroads attracted surplus produce from across central and eastern Iowa. Chicago eventually surpassed Davenport as the great destination for Iowa farm production. The same process worked in western

41. Entries for April 1-April 29, 1848, G. R. Espy Account Book, SHSI-IC.

42 Entries for May 16, 1848-January 15, 1850, William Wright Account Book, SHSI-IC. This source is also an incomplete one, with some pages missing and others pasted over with newspaper articles. 
Iowa, where growing populations were served by improved transportation, which incorporated farms into the greater national market. By 1870 four main railroad lines crossed the state. ${ }^{43}$

As areas became more populated and transportation links improved-especially with railroads in the late $1850 \mathrm{~s}$ and 1860s - advertisements in local papers showed that furniture, kitchen goods, and even pianos had become commonplace. Women replaced their basic utensils with tinware, pewter, and improved types of pots and pans. Stoves replaced open fireplaces, and homemade foods were supplemented by storebought ones. As early as 1837 Dubuque stores advertised "ready made clothing" from New York. Burlington papers contained notices in the 1850s offering silk lace and silk gloves for female consumers. The diary of James Chamberlin, who lived in Johnson County, provides evidence of such mercantile interactions. Chamberlin bought fabric, coffee, tea, yarn, and salt in 1853, trading flour, butter, and peaches to pay for his purchases. He also paid his taxes with income gained from taking goods to merchants. ${ }^{44}$

Historian Earle Ross argued that population growth and settlement led to the rapid development of a home market in Iowa in the 1840s. The state was easily reached by steamboat; more than 30,000 people came by boat from St. Louis in 1842 . The land hunger of settlers, combined with fertile soil and the positive reports from promoters and emigrants, helped draw families into the territory and, after December 1846, state of Iowa. By 1850 the state had more than 190,000 residents, and eastern Iowa was mostly settled, from south of Ottumwa to Dubuque. The large increase in settlement and growth also greatly increased the number of stores and store goods for sale. Overall,

43. Timothy Mahoney, "Down in Davenport: A Regional Perspective on Antebellum Town Economic Development," Annals of Iowa 50 (1990), 451, 459, 463468, 471; William Silag, "The Conquest of the Hinterland: Railroads and Capitalists in Northwest Iowa after the Civil War," Annals of Iowa 50 (1990), 475-77, 486-87, 489-93; Shelton Stromquist, "Town Development, Social Structure, and Industrial Conflict," in Iowa History Reader, ed. Marvin Bergman (Iowa City, 2008), 166-67.

44. Riley, Frontierswomen, 13, 49-50, 62-63, 69, 86; Entries for 1/19/1853, 4/15/ 1853, 4/21/1853, 8/30/1853, 9/17/1853, 11/6/1861, and 2/3/1862, Day Book of James Chamberlin, Special Collections, University of Iowa Libraries, Iowa City. 
prices fell by about half in the 1840s thanks to an increase in the number of stores and the availability of goods. The lives of farm families improved with greater access to less expensive material items. The interest of Iowa settlers in market participation helped the state to develop relatively quickly, especially once railroads better connected the state to the rest of the nation. Nearly 500,000 people settled in Iowa in the 1850s. The state's enormous population growth in the 1850s - which left it with more than 670,000 people by 1860 - further improved the market connections and involvement of its people. By 1870 Iowa's population had almost doubled, reaching 1,194,020. ${ }^{45}$

MARKET PARTICIPATION did not, however, undermine the bonds that tied communities together. Families assisted each other in all phases of life and at all times of the year, from clearing land and harvesting crops to raising homes and taking wheat or pork to market. People exchanged labor, livestock, and foodstuffs with each other and ensured that their neighbors survived and prospered. The Iowa frontier was not the selfsufficient myth of popular imagination but one of shared sacrifice and mutual support. Neighbors served as a "social safety net in a society with little in the way of formal welfare institutions," writes historian David Danbom. Families were part of a network of reciprocity that gave structure to economic and social life. They shared resources, such as timber or pastureland, that were not privately owned. They exchanged work and completed communal labor. "Necessity drove folks together and made them tolerant of each other's personal beliefs and peculiarities," wrote Arthur Pickford. 46

45. Ross, Iowa Agriculture, 21-22, 27-29; Bertha R. Leaman, "An Early Settler in Iowa: Western Expansion in Microcosm," Annals of Iowa 41 (1971), 685; Goodman, "The American Occupation of Iowa," 96-97, 101-2; Morton M. Rosenberg, "The People of Iowa on the Eve of the Civil War," Annals of Iowa 39 (1967), 108; Ainsworth R. Spofford, ed., American Almanac and Treasury of Facts, Statistical, Financial and Political For the Year 1888 (New York, 1888), 283.

46. Danbom, Born in the Country, 91; John Mack Faragher, Sugar Creek: Life on the Illinois Prairie (New Haven, CT, 1986), 137; Arthur Pickford, Westward to Iowa (Mason City, 1940), 56. 
People shared resources and freely exchanged almost any item that another family might need. Families pastured their cattle and sheep on open, unclaimed grasslands; prairies and woods also provided a great place to gather wild fruits, such as crab apples, wild plums, and strawberries. Hunters pursued animals across the countryside in search of meat or furs. Those with extra food often shared it with neighbors. George C. Duffield recalled that extra venison was given to those who had less luck in hunting. Sarah Brewer-Bonebright wrote that extra pork was divided among neighbors who lived near Webster City in north central Iowa. "Utensils were in almost constant use either in our own family or among the neighbors," noted BrewerBonebright. Candle molds were often loaned among neighbors, as were razors and knives. "Borrowing and lending were so freely practiced it would have been difficult for a new arrival to determine to whom personal property belong," she added. Neighbors borrowed horses to help their family get to church. But no one loaned out their guns, the "one possession of a pioneer which he was not willing to lend." 47

Families also assisted each other with mutual labor, including construction, hog butchering, and corn husking, as well as planting and harvesting crops. "People had nothing but work, church and their neighbors," recalled Sarah E. Carmichael, whose family lived close to Ottumwa. Communal labor helped families meet their own housing and food needs and helped to knit communities closer together. Men butchered hogs together and made trips with each other to Keokuk to market their surplus pork before railroads arrived, she remembered. Men also journeyed together to take surplus farm goods to other markets, such as Des Moines or Dubuque. Families joined together to make sauerkraut, bringing salt and cabbage and working together to ensure that every family had a winter's supply. Men met to raise homes, stables, barns, and schoolhouses; they also helped to plant or harvest crops or break mules. Women helped care for the sick, provided food for their families at communal events, took part in quilting parties, and provided help to new

47. Brewer-Bonebright, Reminiscences of Newcastle, 40, 50, 128-29, 147, 242; "Memories of Frontier Iowa Related by George C. Duffield," 21-22, SHSI-IC; D. C. Mott, “Fifty Years in Iowa," 6, SHSI-IC. 


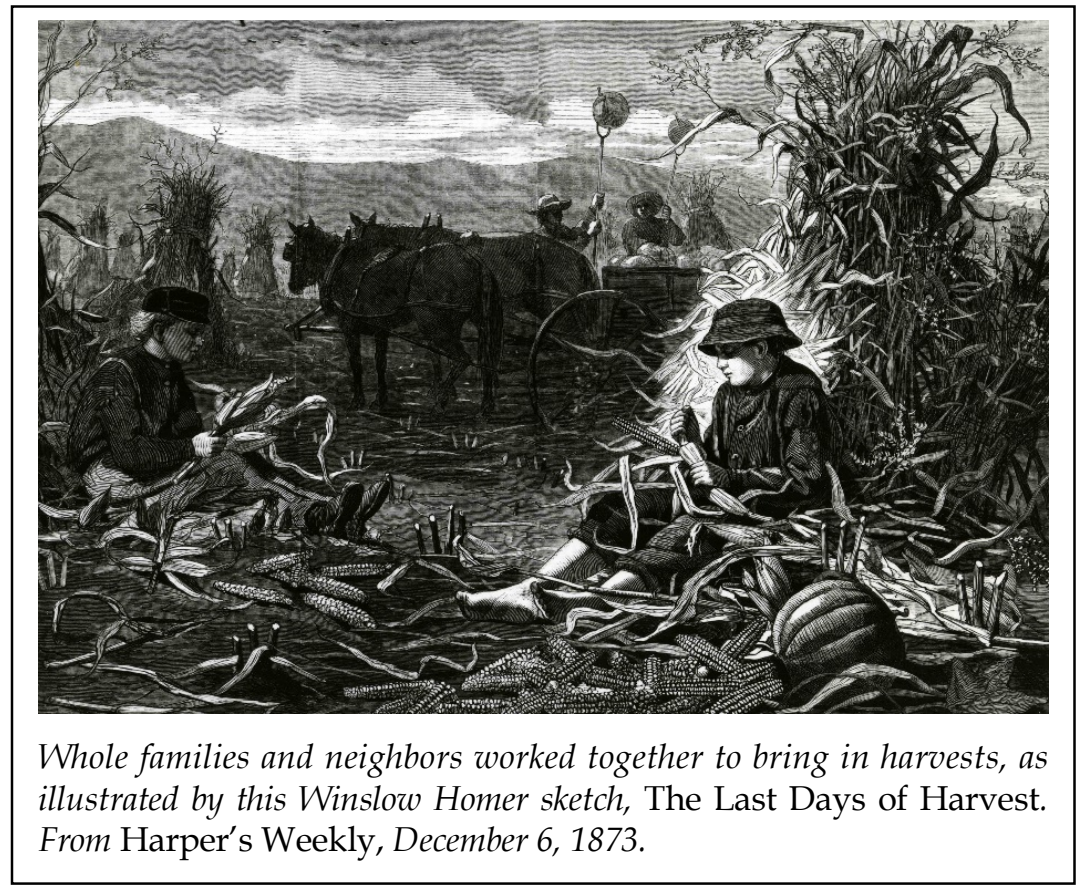

families. William Buxton, who lived near Carlisle, noted in his diary that he helped one neighbor raise a stable in February and helped another build a house in March. He then helped another man sow wheat in April and yet another neighbor plant corn in May. He also helped build a sawmill in May. Young people arranged corn huskings, meeting at night, usually away from adult supervision, to work and play. All of this cooperation helped families feed and house themselves and participate in markets. ${ }^{48}$

Families aided each other regularly, while also enjoying the social interaction with their neighbors. "All newcomers made welcome the same way," recalled Keokuk County resident So-

48. Sarah E. Carmichael, Reminiscences and Happenings of the Past 81 Years (Richland, 1926), 6-7, 30; John Hall, "Early Pioneer Days," SHSI-IC; Swaney, "When Jackson County Was the 'Far West,'” SHSI-IC; Entries for 2/2/1855, 3/9/1855, 4/12/1855, 4/13/1855, 5/3/1855, 5/4/1855, 5/7/1855, 5/8/1855, William Buxton Journal, SHSI-IC; Florence Call Cowles, Early Algona (Des Moines Company, 1964), 85-88; Standfield, "History of Plank Township," 64-65; "Memories of Nellie Oberton Sherman," SHSI-IC. 
phia Standfield. In case of sickness or labor shortage, "neighbors came promptly to assist as long as was necessary. A common sympathy drew them together." When one woman was sick, a neighbor cared for her infant. One woman had her husband row her across the flooded Skunk River to care for a sick friend. Gro Svendsen helped write letters for her neighbors around Estherville. "Many here who can write but very few who can compose letters," she noted. Families visited each other at all times of the year. Mary St. John noted that her family in Saratoga had visitors or went to see a neighbor about one in every four days. This friendliness continued even into the depths of winter. "The strains of winter did not cut off sociability and friendly intercourse among the settlers," remembered William J. Haddock, who lived near Cedar Rapids. Young people enjoyed sleigh rides, spelling contests, and parties, while older men organized debating societies and "aired their vanity and oratory." 49

PEOPLE who came to Iowa in the mid-nineteenth century arrived with a strong commercial orientation. They accepted the need to participate in the expanding market system of the United States. Families pursued the chance to sell farm goods at almost every opportunity and used any profits to invest in buying land or in making their lives a bit more comfortable by purchasing material goods at stores. They accepted and understood the need to earn a profit to achieve their economic goals and emigrated to Iowa to buy land and provide for future generations. Securing capital for land or store goods did not mean that families produced goods only for market, as almost every farm family had to provide some of their own food. But Iowans were not solely self-sufficient farmers. They pursued the opportunity to exchange surplus goods at local stores for items they could not, or chose not to, make for themselves. Such items included necessities, such as powder, tools, and nails, as well as luxuries that made life easier or more pleasant, such as sugar, coffee, alcohol, or tobacco. Merchants helped meet this burgeoning de-

49. Standfield, "History of Plank Township," 64-66; Cowles, Early Algona, 87-88; Svendsen, Frontier Mother, 125; William J. Haddock, A Reminiscence of the Prairies of Iowa and Other Notes (Iowa City, 1901), 40-42; Entries for 5/1-31/1858, Mary St. John Diary, SHSI-IC. 
mand for goods, following their customers into and across Iowa and helping to transform the prairies and forests of Iowa along with the people that bought their products. Communal labor and assistance helped families feed themselves and become involved in the burgeoning market economy. Such neighborhood bonds operated as a welfare network that provided companionship and comfort to families regardless of season. While life was challenging and filled with hard work, the common pursuit of shared goals helped families support each other. 